Variation in body measurements and semen quality of Nigeria sheep breeds "Agbaye, F. P., ${ }^{* *}$ Sokunbi, A. O., ${ }^{*}$ Onigemo, M. A., **Alaba, O, ${ }^{*}$ Anjola, O. A. J., ${ }^{* * *}$ Amao, E. A., ${ }^{* *}$ Oso, Y. A. A., *Agbalaya, K. K., *Ishola, O. J. and "Yusuf, B. "Department of Animal Production Technology, Lagos State Polytechnic, Lagos ${ }^{* *}$ Department of Animal Science, University of Ibadan, Ibadan. Department of Animal Production Technology, The Oke Ogun Polytechnic, Saki.

Abstract

Corresponding author: peteragbaye@gmail.com

small holder farmers enjoy in rearing small ruminants however, there are paucity of information on the morphometric traits and semen characteristics of Nigeria breeds of sheep in Ikorodu. Therefore, the effects of breeds on body measurements and semen quality of four sheep breeds in Nigeria were assessed. Twenty matured rams aged 21/2 years and weighed $31.13 \pm 4.8 \mathrm{~kg}$ comprising five rams per breed namely: Balami (BAL), Ouda (UD), Yankasa (YAK) and West African Dwarf (WAD) were used for the study. Body measurements and semen quality of each ram was assessed for a period of six weeks after the four weeks of acclimatization. Live body weights (LBW), scrotal circumference (SC), height at wither $(H t W)$, rump length (RpL) and rectal temperature (RT) were evaluated for body parameters. Semen samples were collected using electro-ejaculation method and evaluated for semen volume (SV), progressive sperm motility (PSM), sperm concentration (SC), normal sperm morphology (NSM), sperm livability (SL), and sperm acrosome integrity (SAI) using standard procedures. Results revealed that Yankasa had significantly $(p<0.05)$ the higher live body weights (38.33kg) Live body weights while WAD recorded the least live body weights (28.50kg) live body weights which, was similar $(p>0.05)$ with values recorded for Balami (28.67kg) and Ouda $(29.0 \mathrm{~kg})$ breeds. Scrotal circumference was significantly $(p<0.05)$ the lowest $(24.50 \mathrm{~cm})$ in WAD but were similar $(p>0.05)$ in Ouda $(28.00 \mathrm{~cm})$, BAL $(27.67 \mathrm{~cm})$ and $Y A K(26.33 \mathrm{~cm})$. The HtW showed similar trend with scrotal circumference. Meanwhile, there were no significant variation ( $p>0.05$ ) in the value recorded for $R p L(\mathrm{~cm})$ and $R T\left({ }^{\circ} C\right)$. While, PSM, SAI and SV for all the breeds of sheep were statistically similar $(p>0.05)$ in values and SC, SL and SNM were statistically different $(p<0.05)$ between breeds.

Keywords: Body measurement, semen quality, sheep breeds

Variation des mesures corporelles et de la qualité du sperme des races de moutons du Nigeria

\title{
Résumé
}

La petite taille corporelle, la capacité de production élevée et les taux de croissance rapides des moutons sont des caractéristiques remarquables que les petits exploitants agricoles apprécient dans l'élevage de petits ruminants, cependant, il y a peu d'informations sur les traits morphométriques et les caractéristiques du sperme des races de moutons du Nigeria à Ikorodu. Par conséquent, les effets des races sur les mésures corporelles et la qualité du sperme de quatre races de moutons au Nigéria ont été évalués. Vingt béliers matures âgés de 2 ans et demi et pesant 31,13 4,8 kg comprenant cinq béliers par race à savoir: Balami (BAL), Ouda (UD), Yankasa (YAK) et mouton nain de l'Afrique de l'Ouest (WAD) ont été utilisés pour l'étude. Les mesures corporelles et la qualité du sperme de chaque bélier ont été évaluées pendant une période de six semaines après les quatre semaines d'acclimatation. Les poids corporels vivants ( $L B W)$, la circonférence scrotale (SC), la hauteur au garrot (HtW), la 


\section{Variation in body measurements and semen quality of Nigeria sheep breeds}

longueur de la croupe (RpL) et la température rectale (RT) ont été évaluées pour les paramètres corporels. Des échantillons de sperme ont été collectés à l'aide de la méthode d'électro-éjaculation et évalués pour le volume de sperme (SV), la motilité progressive des spermatozoïdes (PSM), la concentration de spermatozoïdes (SC), la morphologie normale des spermatozoïdes (NSM), l'habitabilité des spermatozoïdes (SL) et l'intégrité des acrosomes du sperme (SAI) en utilisant des procédures standard. Les résultats ont révélé que Yankasa avait significativement $(p<0,05)$ les poids corporels vivants les plus élevés $(38,33$ $\mathrm{kg})$, tandis que WAD a enregistré les poids corporels vivants les moins élevés $(28,50 \mathrm{~kg})$ qui étaient similaires ( $p>0,05)$ avec des valeurs enregistrées pour les races Balami $(28,67 \mathrm{~kg})$ et Ouda (29,0 kg). La circonférence scrotale était significativement $(p<0,05)$ la plus basse $(24,50 \mathrm{~cm})$ dans le mouton nain de l'Afrique de l'Ouest mais était similaire $(p>0,05)$ chez Ouda $(28,00 \mathrm{~cm})$, BAL $(27,67 \mathrm{~cm})$ et YAK $(26,33 \mathrm{~cm})$. La hauteur au garrot $(\mathrm{HtW})$ a montré une tendance similaire avec la circonférence scrotale. Pendant ce temps, il n'y avait pas de variation significative $(p>0,05)$ dans la valeur enregistrée pour la longueur de la croupe $(R p L)(\mathrm{cm})$ et la température rectale $(R T)\left({ }^{\circ} \mathrm{C}\right)$. Alors que PSM, SAI et SV pour toutes les races de moutons étaient statistiquement similaires ( $p>0,05)$ en valeurs et $S C$, $S L$ et $S N M$ étaient statistiquement différents $(p<0,05)$ entre les races.

Mots-clés: Mesure corporelle, qualité du sperme, races de moutons.

\section{Introduction}

Domestic sheep differ from their wild ovines relatives and ancestors in several respects, having become uniquely' neotenic' as a result of selective breeding by humans (Carol, 2001). The economic importance of sheep in developing nation cannot be over - emphasized (Alahira, 2013). Sheep with their small body size, high productive capacity and rapid growth rates are ideally suited for production by rural and urban poor small holders. In subSaharan Africa, sheep provide almost 30\% of the meat consumed and around $16 \%$ of the milk (Alahira, 2013). Sheep contributes about $50 \%$ of the total domestically produced meat in Nigeria. Nigeria has about 22.1 million sheep which are distributed over a wide variety of environment. Indigenous sheep have good hearing, and are sensitive to noise when being handled (Carol et al., 2001). Several breeds of sheep have been identified by FAO (Food and Agriculture Organization of the UN) with estimated number varying from time to time. 863 breeds as of 1993 were reported by Maijala (1997), 1314 breeds as of 1995 reported by Scherf (2000) and 1229 breeds as of 2006 (FAO, 2007). However, in Nigeria there are four prominent genotypes namely: West African Dwarf, Yankasa, Ouda, and Balami. But other breeds that are of less importance exist which include the Ara-Ara in Anambra state (RIM, 1989). The West African dwarf is the predominant breed of the humid tropics from southern West Africa through central Africa. The West African Dwarf is a small bodied, compact breed which maybe white, black, brown or spotted black or brown on a white coat. Yankassa is a meat breed found in North and North central Nigeria. They are medium sized breed of sheep. The tail is long and thin, the ears moderately long and somewhat droopy. Rams have curved horns and a hairy white mane and ewes are polled. They have white coat colour with black patches around the eye, ears and muzzle (Weaver, 2005). The Ouda breed is also known as Bororo or Fulani is found in the Northern Nigeria, Southern Niger, Central Chad, Northern Cameroun and Western Sudan. It is one of the hair breeds of Sahel type. It is also a meat breed; it is long legged breed with distinctive coat colour of brown or black anterior and white posterior. They 
are large with straight and long face; they are slightly small bodied than Balami. The Balami breed is the largest bodied native sheep in Nigeria it is confined to the semiarid north but it is favoured as a stall-fed breed throughout the Nigerian middle belt. It is white and hairy with pendulous ears, long leg and a long thin tail. Rams are horned but ewes are normally polled. Other features that make the Balami ram distinctly recognizable is its Roman bulbous nose that distinguish it from Yankasa.

This study was carried out to assess the effect of breed on the body measurements and semen quality of indigenous sheep.

\section{Materials and methods Experimental site}

This Study was carried out at the small ruminant unit and the Veterinary Clinic of the Department of Animal Production Technology, Lagos State Polytechnic, Ikorodu, Lagos state, Nigeria.

\section{Experimental animal and management}

Twenty matured rams comprising five rams per breed from the four prominent breeds with average age of $2 \frac{1}{2}$ years weighing $31.13 \pm 4.8 \mathrm{~kg}$ viz: Yankassa, Ouda, West African Dwarf (WAD) and Balami. The animals were purchased and managed in the small ruminant unit of the Polytechnic Teaching and Research Farm for a period of four weeks to acclimatize and for necessary prophylactic medication before the commencement of the experiment. The rams were allowed to graze within the paddock around the small ruminant housing unit and water was given ad-libitum. Salt lick and supplementary feeds (wheat offal) were given once a day.

\section{Data collection and analysis}

Data on live body weight, height at wither, rump length, scrotal circumference and rectal temperature were collected on each ram weekly for six weeks.

\section{Live body weight}

Body weight was measure by using weighing balance as described by Yakubu et al. (2005).

\section{Height at wither}

Withers height was measured by placing a flexible tape rule between the most cranial palpable spinous process and the ground and it was recorded as described by Yakubu et al. (2005).

\section{Rumplength}

This was assessed by placing a flexible tape rule to measure from hips (Tuber coxae) to pins (Tuber ischia) following the methods of Yakubu et al. (2005).

\section{Scrotal circumference}

The testes were held at the bottom of the scrotum by applying pressure to the dorsal aspect of the testes at the neck of the scrotum. The largest circumference was measured with a flexible tape rule as described by Vencato et al. (2014).

\section{Rectal temperature}

The rectal temperature was assessed by placing a digital thermometer in the rectum of the ram about $1 / 2$ inch and removed after it beeped and the digits in the window on the thermometer was recorded (Yakubu, et al., 2005)

\section{Semen collection and analysis}

Semen samples were collected from the ram weekly for six consecutive weeks in a graduated tube with the use of electroejaculation method as described by Oyeyemi et al. (2002). The samples were analyzed for, semen volume, sperm progressive motility, sperm normal morphology, sperm concentration, sperm livability and sperm acrosome integrity.

\section{Semen volume}

Semen volume was estimated using the calibration on the tube used for collection.

\section{Progressive sperm motility}

A drop of freshly collected semen sample was mixed with normal saline solution on a clean warm glass slide, covered with a cover slip and examined with light microscope at $\mathrm{x} 40$ magnification as described by Ewuola and Egbunike (2010). 
Variation in body measurements and semen quality of Nigeria sheep breeds

\section{Normal sperm morphology}

A drop of freshly collected semen was placed on a clean warm glass slide, and a drop of eosin-nigrosin stain was added. The semen and the stain were mixed together gently, and a thin smear was made on another clean warm slide. The slide was observed under oil immersion using a phase contrast microscope as described by Ewuola and Egbunike (2010). One hundred spermatozoa were counted and the proportion of the hundred spermatozoa with normal morphological appearance was recorded.

\section{Spermatozoa concentration}

Sperm cells concentration was assessed by using Neubauer haemocytometer after diluting with formal saline solution (Ewuola and Egbunike, 2010). A drop of the sample was filled into the counting chambers and the numbers of spermatozoa in four (4) fields of the counting were recorded.

\section{Spermatozoa livability}

Percentage of live spermatozoa in the semen sample was evaluated by placing a drop of semen on a warm glass slide; one drop of eosin-nigrosin stain was added and mixed gently. It was smeared on a slide with the edge of another clean slide, air dried and viewed under the microscope at magnification of $\mathrm{x} 400$. One hundred spermatozoa were counted and the number of live cells (cells that did not absorbed stain were observed as representing the cells that are still living while those stained represents dead spermatozoa) as described by Oyeyemi, et al. (2002)

\section{Spermatozoa acrosome integrity}

This was assessed by mixing a $100 \mu 1$ semen sample with $500 \mu 1$ of $1 \%$ formal citrate $(2.9$ g) tri-sodium citrate dehydrate, $1 \mathrm{ml}$ of $37 \%$ solution of formaldehyde in $100 \mathrm{~mL}$ of distilled water). One hundred spermatozoa per sample were counted with phase contrast microscope x1000 under oil immersion (Muhammad et al., 2011). One hundred sperm cells were counted and those with intact acrosome among the hundred were observed.

\section{Statistical analysis}

Data collected were subjected to analysis of variance (ANOVA) according to the standard procedure as described by Steel and Torrie (2002). Duncan multiple range test was used to compare the means.

\section{Results}

Semen characteristics of indigenous breeds of ram

Table 1 showed that spermatozoa progressive motility, spermatozoa acrosome integrity and semen volume were not significantly different $(\mathrm{p}>0.05)$ among the breeds, while spermatozoa concentration, normal sperm morphology and the spermatozoa livability differs significantly $(p<0.05)$ for the different breeds of sheep.

\section{Mean body measurements of indigenous breeds of ram}

Table 2 shows that there was significant difference $(\mathrm{p}<0.05)$ between the Live body weight, scrotal circumference and withers height of the different breeds of ram, but the rectal temperature and rump length were not significantly different $(\mathrm{p}>0.05)$.

Table 1: Semen characteristics of indigenous breeds of ram in Nigeria

\begin{tabular}{|c|c|c|c|c|c|}
\hline \multirow{2}{*}{ Parameters } & \multicolumn{4}{|c|}{ Breeds of ram } & \multirow{2}{*}{ SEM } \\
\hline & Balami & Yankasa & WAD & Ouda & \\
\hline PSM (\%) & 96.33 & 95.00 & 92.67 & 93.00 & 0.86 \\
\hline $\mathrm{SC}\left(\mathrm{x} 10^{6} / \mathrm{mL}\right)$ & $136^{\mathrm{a}}$ & $128^{a}$ & $125.33^{\mathrm{b}}$ & $111^{\mathrm{b}}$ & 5.21 \\
\hline SL $(\%)$ & $98.00^{\mathrm{a}}$ & $98.67^{\mathrm{a}}$ & $97.33^{\mathrm{a}}$ & $93.33^{\mathrm{b}}$ & 1.20 \\
\hline NSM (\%) & $97.33^{\mathrm{ab}}$ & $98.67^{\mathrm{a}}$ & $94.00^{\mathrm{b}}$ & $97.00^{\mathrm{ab}}$ & 0.99 \\
\hline SAI $(\%)$ & 97.67 & 97.67 & 97.00 & 96.33 & 0.32 \\
\hline $\mathrm{SV}(\mathrm{mL})$ & 0.37 & 0.45 & 0.45 & 0.35 & 0.035 \\
\hline
\end{tabular}

${ }^{\mathrm{ab}}$ Means figures with the same superscript in the same rows are not significantly difference $(\mathrm{p}>0.05)$. $\mathrm{SV}=$ Semen Volume, PSM= Progressive Sperm Motility, SC= Sperm Concentration, SL=Sperm Livability, $\mathrm{NSM}=$ Normal Sperm Morphology, SAI=Sperm Acrosome Integrity. 
Agbaye, Sokunbi, Onigemo, Alaba, Anjola, Amao, Oso, Agbalaya, Ishola and Yusuf

Table 2: Mean body measurements of indigenous breeds of ram in Nigeria

\begin{tabular}{|c|c|c|c|c|c|}
\hline \multirow{2}{*}{ Parameters } & \multicolumn{4}{|c|}{ Breeds of ram } & \multirow{2}{*}{ SEM } \\
\hline & Balami & Yankasa & WAD & Ouda & \\
\hline LBW (kg) & $28.67^{\mathrm{b}}$ & $38.33^{\mathrm{a}}$ & $28.50^{\mathrm{b}}$ & $29.00^{\mathrm{b}}$ & 2.40 \\
\hline $\mathrm{SC}(\mathrm{cm})$ & $27.67^{\mathrm{a}}$ & $26.33^{\mathrm{ab}}$ & $24.50^{\mathrm{b}}$ & $28.00^{\mathrm{a}}$ & 0.79 \\
\hline $\mathrm{HtW}(\mathrm{cm})$ & $68.33^{\mathrm{a}}$ & $67.67^{\mathrm{a}}$ & $55.33^{\mathrm{b}}$ & $68.40^{\mathrm{a}}$ & 3.21 \\
\hline $\mathrm{RpL}(\mathrm{cm})$ & 70.40 & 71.57 & 68.87 & 72.07 & 0.73 \\
\hline $\mathrm{RT}\left({ }^{0} \mathrm{c}\right)$ & 38.50 & 38.33 & 38.40 & 38.67 & 0.04 \\
\hline
\end{tabular}

${ }^{\mathrm{ab}}$ Mean with the same superscript in the same rows are not significant difference $(\mathrm{p}>0.05)$

$\mathrm{LBWt},=$ Live Body weight, $\mathrm{SC}=$ Scrotal circumference, $\mathrm{HtW}=$ Height at Wither, $\mathrm{RpL}=$ Rump Length, $\mathrm{RT}=$ Rectal Temperature

\section{Discussion}

The result showed that the progressive motility of spermatozoa in fresh semen sample of Nigerian sheep breeds ranges between 93.0 and $96.33 \%$. This result was higher than $83.0 \%$ and $80 \%$ reported by Oyeyemi et al. (2009). The mean spermatozoa concentrations were between 110 and $136 \times 10^{6}$. This is higher than 35 and $60 \times 10^{6} \mathrm{sperm} / \mathrm{mL}$ in the ram ejaculate as reported by Evans and Maxwell (1987) but lower than $250 \times 10^{6} \mathrm{sperm} / \mathrm{ml}$ reported by Gil et al. (2003). The variation in the results obtained in this study and other works could be as a result of breed difference between temperate and tropical breeds as well as the environmental influence on the animals. The mean livability ranges between 93.33 and $98.0 \%$. It also shows significant differences between Ouda ram and other breeds. Normal sperm morphology of the rams of the breeds of ram ranges between 94 and $98 \%$ and the difference was not statistically significant. However, the values were far higher than range of 70 $80 \%$ recommended by Kuste et al. (2004). However, range reported in the current study was higher than the value of $85 \%$ and $70 \%$ in boar by Roca et al. (2006) and this could be attributed to species difference. Spermatozoa acrosome integrity ranges from $96.33-97.67 \%$ and it was not significantly different between the ram breeds. The semen volume obtained in the study ranges between $0.35-0.45 \mathrm{~mL}$ which is lower than $0.5-2.0 \mathrm{~mL}$ for matured rams and $0.5-0.7 \mathrm{~mL}$ for young rams by Hafez and Hafez (2000). The variation could be as a result of genetic superiority between temperate and tropical breed of animal. The live body weight is between 28.67 and $38.33 \mathrm{~kg}$. Yankassa breed was statically higher in live body weight compare to other breeds. The body weight of an animal could be affected by feed, age and environmental factors. Animals used for this study were aged between 2 to 3 years and were kept under the same management. The scrotal circumference of the different breeds of sheep ranges from $24.5-28 \mathrm{~cm}$. Smith and Somade (1994) observed that scrotal circumference is greatest during the month of August-October. Al-Ghalban et al. (2004) reported higher scrotal circumference during autumn months for buck. The mean height at wither was ranged $55.33-68.40 \mathrm{~cm}$ and it was significantly lower in WAD when compared to other breeds. The value reported for Yankassa ram obtained in this study is lower than 70.0 $+3.6 \mathrm{~cm}$ recorded by Dauda (1984). Height at wither of Ouda ram and other breeds except WAD fall within recommended. The rump length and rectal temperature of the breeds of sheep ranges between 68.87 $72.07 \mathrm{~cm}$ and it was not significant among the breeds studied.

\section{Conclusion}

The study showed breed variation in some semen characteristic of indigenous breeds of sheep. It showed that the West African 
Dwarf breeds of sheep have the lowest spermatozoa motility compared to Balami, Yankassa and Ouda breeds although the variation was not outstanding.

\section{References}

Al-Ghalban, A. M., Tabba, J. and Kridli, R. T. 2004. Factors affecting semen characteristics and scrotal circumference of Damascus bucks. Small Rumin. Res. 53(1-2):141149.

Alahira, J. 2013. All You Need to Know About Sheep Production. In: Livestock Production. Agriculture $\mathrm{N}$ i $\mathrm{g}$ e $\mathrm{r}$ i $\mathrm{a}$. https://www.agriculturenigeria.co $\mathrm{m} / \mathrm{manuals} /$ production/livestock production/sheep/

Carol, E. 2001. Storey's Guide to Raising sheep, MA: Storey Publishing LLC.ISBN 978-1-58017-262-2.

Dauda, C. S. 1984. Yankassa Ram: Body weight, withers height, scrotal and penis size and sperm reserves. Sheep and Goat Research Journal 2(2): 126-128. Development Institute.

Evans, G. and Maxwell, W. M. C. 1987. Salamon's Artificial Insemination of sheep and Goats. Butterworths, Sydney, Australia, pp.194.

Ewuola, E. O. and Egbunike, G. N. 2010. Gonadal and extra-gonad sperm reserves and sperm production of puberty rabbits fed dietary fummonisin B1. Journal of Animal Reproduction Science, 119(2010) pp.282-286.

FAO, 2007. State of the world's animal genetics resources for food and agriculture. $512 \mathrm{pp}$.

Gil, J., Lunderheim, N., Soderquist, L. and Rodriguez-Martinez, $H$. 2003. Influence of extender, temperature, and addition of glycerol on post-thaw sperm parameters $n$ ram semen. Theriogenology, 59: 1241-1255.

Hafez, B. and Hafez, E. S. E. 2000. Reproduction in Farm Animals $7^{\text {th }}$ edition. Lippincott Williams and Wilkens, New York, pp.509.

Kuster, C. E., Singer, R. S. and Althouse, G. C. 2004. Determining sample size for the morphology of semen a s s e s sment of s perm. Theriogenology 61(4):691-703.

Maijala, K. 1997. Genetics aspects of domestication, common breeds and their origin. In: Piper, L. and A. Rusvinsky (eds.). The geneyics of sheep.CA

Muhammad, S. A., Bushra, A. R., Nemat, U., Syed, M. H. A., Muhammad, K. and Shamim A. 2011. Effect of L. Cysteine in Tris-citric Egg Yolk Extender on Post Thaw Quality of Nili-Ravi Bufaalo (Bubalus bubalis) Bull Spermatozoa. Pakistan J. Zool., vol.43 (1), pp.4147.

Oyeyemi, M. O., Akusu, M. O. and OlaDavies, O. E. 2002. Effect of successive ejaculation on the spermiogram of West African Dwarf goats (Capra hircus L). Vet. Arc. 70:215-221.

RIM, 1992. Nigerian National Livestock Resource Survey. (IV vols). Report by Resource

Roca, J., Hernández, M., Carvajal, G. and Vazquez, J. M. 2006. Factors influencing boar sperm cryosurvival. Journal of Animal Science 84(10):2692-9 DOI: $10.2527 /$ jas.2006-094

Scherf, B. D. 2000. World watch list for domestic animal diversity. $3^{\text {rd }}$ Edition F.A.O, Rome. 726pp.

Smith, O. B. and Somade B. 1994. Interaction between nutrition and reproduction in farm animal. Proceeding of IFS JAN 17-21. 
Pp.7-25.

Steel, R. G. D. and Torrie, J. H. 2002.

Principles and procedures of statistics, McGraw-Hill, New York.

Vencato, J., Romanoli, S., Stelleta, C. 2014 . Tran s s c rot a 1 ultrasonography and testicular fine needle aspiration cytology in the evaluation of ram sperm production. Small Ruminant Research 120:112-115.
Weaver, S. 2005. Sheep: Small, scale sheep keeping for pleasure and profit. ISBN 1-931993-49-1.

Yakubu, A., Abdullah, A. R., Ari, M. M., Ogah, D. M. 2005. Studies on live weight and linear body measurements of West African Dwarf sheep in North Central Nigeria Production Agriculture and Technology, 1, 137-145.

Received: $19^{\text {th }}$ September, 2020 Accepted: $20^{\text {th }}$ December, 2021 